\title{
PREDNOSTI IN PASTI PROSTORSKEGA PLANIRANJA NA REGIONALNI RAVNI
}

\author{
Helena Šolar \\ Ministrstvo za okolje in prostor, Urad za prostorski razvoj, \\ Dunajska 2I, SI-I000 Ljubljana \\ e-mail: helena.solar@gov.si \\ Pregledni znanstveni članek \\ COBISS 1.02
}

\section{Izvleček}

V prispevku so $\mathrm{v}$ uvodu navedeni in utemeljeni razlogi za ponovno uveljavitev prostorskega planiranja na regionalni ravni skozi regionalne zasnove prostorskega razvoja. V osrednjem delu prispevka so predstavljene izkušnje, pridobljene pri vodenju postopkov priprave regionalnih zasnov. Zaključek je namenjen posameznim vsebinam oz. korakom v postopku priprave regionalnih zasnov prostorskega razvoja, kjer se najpogosteje pojavijo odprta vprašanja in problemi in razmisleku, kako odgovoriti nanje.

Ključne besede: prostorsko planiranje, regija, zakon o urejanju prostora, regionalna zasnova prostorskega razvoja;

\section{ADVANTAGES AND RISKS OF SPATIAL PLANNING AT REGIONAL LEVEL}

\begin{abstract}
The article states and arguments the reasons for renewed enforcement of spatial planning at regional level through Regional Concepts of Spatial Development. The focus of the article deals with experience gained through preparation procedures of the Regional Concepts of Spatial Development. The conclusion sets out some of the most important pending questions and expected problems which are directly linked to Regional Concepts of Spatial Development and suggests future perspectives in this field of spatial planning.
\end{abstract}

Key words: spatial planning, region, spatial planning act, regional concept of spatial development. 


\section{IZHODIŠČA}

\section{Utemeljitev potrebe po regionalnem prostorskem planiranju}

Aktivnosti za ponovno uveljavitev regionalnega planiranja $v$ sistemu prostorskega planiranja so utemeljene $\mathrm{z}$ dejstvom, da je prostorsko planiranje lahko najbolj učinkovito prav na regionalni ravni, kjer se neposredno soočajo razvojni interesi posameznih dejavnosti oziroma sektorjev ter njihove pobude za posege v prostor. Na tej ravni se tudi lahko oblikujejo usklajeni skupni interesi lokalnih skupnosti in se soočajo z državnimi interesi. Na drugi strani se velik del nalog države na področju urejanja prostora nanaša na posamezna problemska območja, katerih regionalne posebnosti in značilnosti je potrebno upoštevati.

Skupni prostorski akt države in občin o usklajenem planiranju prostorskih ureditev je podlaga za pripravo prostorskih planskih in izvedbenih aktov države in občin oziroma za njihove spremembe ali dopolnitve. Na državni ravni naj bi bila to predvsem izhodišča za opredelitev območij in koridorjev prostorskih ureditev državnega pomena, na ravni občin pa opredelitev območij infrastrukture regionalnega pomena ter večjih posegov v prostor, ki presegajo potrebe ene občine. Med te spada določanje razvojnih območij, lokacij pomembnejših javnih ustanov, proizvodnih in poslovnih con, lokacij nakupovalnih središč, območij večje komunalne infrastrukture, športno-rekreacijskih območij, kmetijskih območij ter območij varstva naravnih vrednot in kulturne dediščine.

\section{Pojmi}

Pojem regija izvira iz latinske besede "regio, regionis" in pomeni določen teritorij oziroma del zemeljskega površja. Vsebinsko se pojem uporablja različno, v našem primeru predstavljajo regije zaokroženo geografsko območje z jasno določenimi mejami, za katerega se pripravi in sprejme regionalna zasnova prostorskega razvoja.

Regionalni razvojni program je razvojni dokument v katerem se, na podlagi analize stanja in gibanj ter sektorskih razvojnih programov, uskladijo razvojna predvidevanja in naloge države in občin na področju gospodarskega, socialnega, prostorskega in okoljskega ter kulturnega razvoja v regiji.

Regionalno prostorsko planiranje je urejanje človekovega okolja in družbenega delovanja v regiji v želji doseči harmonični ekonomski in socialni razvoj ob upoštevanju danega prostora (Vrišer 1978). Je raziskovanje, usmerjanje in planiranje razmestitve človekovih dejavnosti $\mathrm{v}$ regionalnem prostoru, usklajevanje naravnih zmožnosti prostora $\mathrm{z}$ različnimi interesi uporabnikov ter usmerjanje v premišljeno gospodarjenje s prostorom (Pogačnik, 1999).

Regionalna zasnova prostorskega razvoja ( $\mathrm{v}$ nadaljevanju: regionalna zasnova) je partnerski prostorski akt države in občin, $\mathrm{s}$ katerim se usklajeno planirajo prostorske ureditve na območju regije. Z njo se podrobneje planirajo zasnove prostorskih ureditev državnega pomena in zasnove prostorskih ureditev lokalnega pomena, za katere je smotrno, da jih država in lokalne skupnosti planirajo skupno. Njen ključni cilj je ustvariti prostorske pogoje za celostni in povezan razvoj obstoječih ter novih dejavnosti celotnega območja, za katerega se izdeluje. 


\section{Namen in cilji regionalnih zasnov}

Regionalna zasnova je eden izmed razvojnih dokumentov na regionalni ravni in regionalnemu razvojnem programu odgovarjajoči prostorski del.Z regionalno zasnovo se določi konceptualne rešitve glede rabe prostora, podrobnejše usmeritve prostorskega razvoja na obravnavanem območju, zasnovo projektnih rešitev prostorskih ureditev z njihovimi ureditvenimi območji in program ukrepov za izvajanje regionalne zasnove.

\section{REGIONALNE ZASNOVE PROSTORSKEGA RAZVOJA}

\section{Nove težnje in njihove posledice}

Pomemben prispevek in vpliv na oblikovanje bodočega sistema regionalnega prostorskega planiranja ima Zakon o spodbujanju skladnega regionalnega razvoja (Uradni list RS 60/99, 56/2003),. Spodbujanje skladnega regionalnega razvoja je sestavina regionalne strukturne politike Slovenije, katere ciljje uravnotežen gospodarski, socialni in prostorski razvoj. Zavzema se za zmanjšanje razlik v gospodarski razvitosti in življenjskih možnostih med regijami in preprečevanje nastanka novih območij z večjimi razvojnimi problemi. Ob upoštevanju Strategije prostorskega razvoja Slovenije naj bi prispevala k ohranitvi poseljenosti celotnega območja Slovenije in pospešila razvoj okolju prijaznega gospodarstva ter varovanje naravnih in ustvarjenih danosti.

Z Zakonom o spodbujanju skladnega regionalnega razvoja je vzpostavljen osnovni okvir celovitega razvojnega planiranja na regionalni ravni, v katerem je določitev prostorskih razvojnih pogojev, omejitev in usmeritev temeljni pogoj za sprejem uresničljivih razvojnih odločitev. V regionalnih razvojnih programih, ki so jih glede na zakon dolžne izdelati regije za celotno območje Slovenije, se usklajujejo razvojna predvidevanja na področju gospodarskega, socialnega, prostorskega, okoljskega in kulturnega razvoja regije. Smiselno je, da hkrati regije pristopijo tudi k pripravi ustreznega prostorskega akta za isto območje. Le ta je namreč pogoj za usklajeno izvajanje regionalnih razvojnih programov v prostoru oziroma posameznih nalog iz regionalnih razvojnih programov, ki se odražajo v prostoru.

Na drugi strani Zakon o urejanju prostora (Uradni list RS, št. 110/02, 8/03 - popr. in 58/03-ZZK-1), ki teži k skladnemu prostorskemu razvoju z usklajevanjem gospodarskih, družbenih in okoljskih vidikov razvoja, uveljavlja regionalne zasnove prostorskega razvoja (v nadaljevanju: regionalna zasnova) kot partnerske prostorske planske akte države in občin, povezanih v regijah. S temi akti, ki jih sprejmejo Vlada RS in občine, so v skladu z načeli trajno uravnoteženega prostorskega razvoja določene prostorske ureditve regionalnega pomena ter podane usmeritve za pripravo prostorskih planskih in izvedbenih aktov države in občin oziroma za njihove spremembe in dopolnitve. Hkrati je s tem vzpostavljena povezava s pripravo in uresničevanjem regionalnih razvojnih programov.

\section{Razlogi za pripravo regionalne zasnove prostorskega razvoja}

$\mathrm{V}$ dosedanjem sistemu planiranja, kjer je bila izpuščena regionalna raven, je država praviloma občinam brez usklajevanja predložila določene planske usmeritve. Lokalna raven jih je 
ponavadi, če je le mogla, poskušala ustaviti ali v najboljšem primeru vsaj spremeniti. Na drugi strani se, zaradi drobljenja občin, lokalna raven vse težje spopada s prostorskimi problemi, ki $\mathrm{v}$ večini primerov presegajo moč in potrebe ene same občine. Zato je $\mathrm{z}$ regionalno zasnovo potrebno uskladiti prostorske planske odločitve med državo na eni ter občinami na drugi strani ter hkrati med občinami samimi. Na državni ravni gre za izhodišča Strategije prostorskega razvoja Slovenije, na občinski pa za uskladitev izhodišč za opredelitev območij infrastrukture regionalnega pomena ter večje posege v prostor, ki presegajo potrebe ene občine. Sprejeta regionalna zasnova, skupni prostorski akt države in občin, je nato podlaga za pripravo prostorskih planskih in izvedbenih aktov države in občin, oziroma za njihove spremembe in dopolnitve.

\section{Predmet in programska izhodišča regionalne zasnove}

Regionalna zasnova mora biti oblikovana kot partnerski akt med državo in občinami. Zato so ključni cilji, ki jih je potrebno doseči:

- umestitev državnih prostorskih interesov v prostorski razvoj regije,

- oblikovanje in prostorska umestitev območij in ureditev regionalnega pomena,

- uskladitev in dopolnitev regionalnih vsebin v obstoječih prostorskih planskih dokumentih občin.

Programska izhodišča regionalne zasnove so nabor prostorskih vsebin regionalnega pomena, ki so prioritetne $\mathrm{v}$ regiji in morajo zato tvoriti jedro vsebine regionalne zasnove. Ker je ta raven zaenkrat še nedorečena in do sprejetja zakona o pokrajinah nima nobenih zakonskih pristojnosti, so med regionalne vsebine uvrščeni tisti prostorski projekti, ki presegajo potrebe zgolj ene občine.

\section{Vsebinska izhodišča}

V skladu s splošnimi razvojnimi cilji je pri pripravi regionalne zasnove treba upoštevati vse tri ravni odločanja (državno, regionalno in občinsko) in njihova izhodišča. Državna izhodišča so podana $\mathrm{v}$ ustreznih državnih dokumentih, regionalna $\mathrm{v}$ sprejetem regionalnem razvojnem programu, občinska pa v občinskih dokumentih. Regionalna zasnova mora prostorsko preveriti, medsebojno uskladiti ter ustrezno umestiti v prostor vse za nadaljnji razvoj pomembne vsebine, katerih nabor se med izdelavo regionalne zasnove še dopolnjuje.

$\mathrm{Z}$ regionalno zasnovo je treba prostorsko uskladiti in umestiti predvsem tiste ključne prostorske projekte, ki so vitalnega pomena za nadaljnji razvoj regije. Na področju poselitve so to:

- umestitev regionalnega in subregionalnih središč, pomembnih za oskrbo posameznih območij znotraj regije in območij za razvoj gospodarskih in družbenih dejavnosti, vključno z opredelitvijo njihovih funkcij in posledičnih prostorskih ureditev,

- na področju infrastrukture izgradnja avtocest, regionalnih cest in železniških povezav, ki bodo omogočile boljši gospodarski razvoj, izgradnja daljinskega, državnega in regijskega kolesarskega omrežja, ureditev prometnih terminalov za kombiniran tovorni promet, umestitev skupnih čistilnih naprav, izgradnja vodovodov in opredelitev sistema za ravnanje z odpadki v regiji oz. subregijah, izboljšanje energetske opremljenosti regije, izgradnja letališča ter tranzitnega magistralnega plinovoda in daljnovodov in 
- na področju varovanja in razvoja narave, naravnih virov in kulturne dediščine urejanje večjih območij agrarnih operacij na območju celotne regije, oblikovanje regijskih in krajinskih parkov, pri čemer se ta območja obravnavajo kot naravne vrednote in hkrati kot potencial za razvoj turizma in rekreacije, urejanje drugih pomembnejših območij kulturne dediščine, vodnogospodarske ureditve, urejanje območij za pridobivanje mineralnih surovin, sanacija opuščenih kopov in določitev območij kmetijskih operacij ter območij prednostnega uveljavljanja ukrepov za spodbujanje kmetijstva, ki bo tudi v povezavi s turizmom zagotavljalo nadaljnjo poseljenost in vzdrževalo kulturno pokrajino.

\section{POSTOPEK PRIPRAVE REGIONALNE ZASNOVE}

Vsebinsko vodenje in spremljanje izdelave regionalnih zasnov, ki vključuje izdelavo projektne naloge, oddajo in spremljanje dela, vzpodbujanje s strokovnimi priporočili in s subvencioniranjem izdelave, je v pristojnosti Ministrstva za okolje in prostor.

Pripravljavec regionalne zasnove bi zaradi ravni načrtovanja oz. prostorskih ureditev, ki se z njo načrtujejo in zaradi določb 19. člen ZUreP-1, ki določa, da izdelavo prostorskih aktov (razen lokacijskih načrtov) praviloma financira pripravljavec, morala biti regionalna razvojna agencija ali ena od vključenih občin, s katero pa bi Ministrstvo za okolje in prostor moralo tesno vsebinsko sodelovati.

\section{Pobuda in dogovor o skupnem načrtovanju prostorskih ureditev}

Pobuda za pripravo regionalne zasnove mora vsebovati okvirno vsebino in namen regionalne zasnove s kratko utemeljitvijo, okvirno območje regionalne zasnove in predvidene nosilce urejanja prostora ter druge udeležence, $\mathrm{v}$ katerih delovno področje spadajo načrtovane prostorske ureditve. Ministru za prostor jo lahko pošljejo zainteresirane občine ali ministrstva, iz delokroga katerih so načrtovane prostorske ureditve.

Na podlagi ugotovljene utemeljenosti pobude, minister za prostor predlaga občinamudeleženkam in ministrstvom, $\mathrm{v}$ katerih delovno področje spadajo načrtovane prostorske ureditve, podpis dogovora o skupnem načrtovanju prostorskih ureditev regionalnega pomena in imenuje programski svet. Podpis dogovora o skupnem načrtovanju prostorskih ureditev regionalnega pomena je pogoj za začetek priprave regionalne zasnove.

Odpraviti je treba nepotreben, organizacijsko in časovno zahteven formalizem, kakršen je dogovor o pripravi regionalne zasnove, ki ga podpisujejo župani in pristojni ministri. Isti namen, kakršnega ima dogovor, je namreč dosežen s programom priprave regionalne zasnove, ki mora biti pred sprejemom usklajen z vsemi udeleženci.

\section{Program priprave regionalne zasnove}

Program priprave izdela izmed pobudnikov izbrani pripravljavec regionalne zasnove. V programu priprave mora biti naveden namen regionalne zasnove, ocena stanja, razlogi in pravna podlaga za pripravo regionalne zasnove, predmet in programska izhodišča regionalne zasnove, okvirno ureditveno območje regionalne zasnove, nosilci urejanja prostora, ki dajejo smernice 
in mnenja ter drugi udeleženci, ki bodo sodelovali pri pripravi regionalne zasnove. Opredeljen mora biti način usklajevanja $\mathrm{v}$ primerih neskladij zahtev, seznam potrebnih strokovnih podlag za načrtovanje predvidene prostorske ureditve, način pridobitve strokovnih rešitev, navedba in način pridobitve geodetskih podlag, način upoštevanja oziroma usklajevanja $\mathrm{z}$ regionalnim razvojnim programom, če je ta že sprejet oziroma se za območje ali za del območja regionalne zasnove pripravlja hkrati z regionalno zasnovo, način upoštevanja oziroma usklajevanja $\mathrm{z}$ regionalnimi razvojnimi dokumenti tudi na sosednjih območjih, če ti že obstajajo oziroma se pripravljajo sočasno z regionalno zasnovo, roki za pripravo regionalne zasnove oziroma njenih posameznih faz, obveznosti v zvezi s financiranjem priprave regionalne zasnove in naloge programskega sveta in drugih udeležencev $\mathrm{v}$ postopku priprave in sprejemanja regionalne zasnove ter njenega izvajanja. V programu priprave mora biti, v skladu z določbami Zakona o varstvu okolja (Uradni list RS, št. 41/04) in Zakona o ohranjanju narave (Uradni list RS, št. 96/04, uradno prečiščeno besedilo) opredeljena tudi obveznost izvedbe celovite presoje vplivov njene izvedbe na okolje oziroma presoje sprejemljivosti njenih vplivov na varovana območja, če je bilo to ugotovljeno v postopku določitve planov, ki imajo lahko pomembne vplive na okolje oz. varovana območja.

V primeru regionalne zasnove, ki naj bi bil partnerski oziroma skupni akt države in občin, bi si morali s primernimi spremembami in poenostavitvami postopka predvsem prizadevati za stvarno sodelovanje sektorjev (resorjev) pri oblikovanju planskih odločitev skupaj z občinami, kar je v sedanjem sistemu upravljanja države za večino sektorjev prej moteče in nepotrebno kot koristno. Sodelovanje nosilcev urejanja prostora v postopku načrtovanja je namreč ZUREP1 omejil na izstavitev smernic in mnenj, namesto da bi bilo obvezani da izdelajo strokovne podlage za potrebe priprave prostorskega akta in sodelujejo pri usklajevanju rešitev.

\section{Vsebinski mejniki postopka priprave predloga regionalne zasnove}

Pred začetkom del so organizirani prvi usklajevalni sestanki, na katerih se predstavita potek dela ter način koordinacije in usklajevanja med naročnikom, izdelovalci, državo in občinami - udeleženkami. Izdelovalec mora povzeti in ovrednotiti tiste strokovne podlage državnih organov in njihovih strokovnih služb s posameznih delovnih področij, ki jih je potrebno upoštevati ob izdelavi regionalne zasnove in pripraviti analizo prostorskega plana države. Pri tem morajo nosilci urejanja prostora - državni organi in njihove strokovne službe aktivno sodelovati ter zagotoviti dostopnost svojih projektov in strokovnih podlag in izdelovalcu posredovati svoje smernice. Izdelovalec mora pripraviti analizo ter oceno prostorskih planov občin, vključenih v pripravo regionalne zasnove in pripraviti analizo stanja in trendov $\mathrm{v}$ prostoru ter opredeliti položaj regije oziroma subregij v širšem prostoru. Izdelati mora predlog podrobnejše vsebine regionalne zasnove za vsebine in območja, ki so relevantna za obravnavano raven in območje.

Izdelovalec mora pripraviti vizijo prostorskega razvoja $\mathrm{v}$ regiji, ki mora vsebovati temeljne opredelitve prostorskega razvoja, v okviru katerih se določijo globalni cilji prostorskega razvoja regije v povezavi z razvojem sosednjih regij in tudi čezmejnih povezav ter ob upoštevanju skupnih načel urejanja prostora $v$ državi. Na podlagi usklajene vizije izdelovalec pripravi variantne zasnove prostorskega razvoja po posameznih sistemih v regiji za državni 
in regionalni nivo ter zasnove v subregijah za občinski nivo. Hkrati se v skladu z okoljskimi izhodišči izdela tudi okoljsko poročilo in njegova revizija. Sledi izbor variantne rešitve, ki je podlaga za izdelavo predloga regionalne zasnove.

Izdelovalec pripravi predlog regionalne zasnove, ki mora kot prostorski akt vključevati temeljne cilje in usmeritve urejanja prostora, zasnovo prostorskih sistemov - poselitve, infrastrukturnih sistemov in sistema varovanja in razvoja narave, naravnih virov in kulturne dediščine ter smernice in ukrepe za njeno izvajanje. Predlog dokumenta mora biti pripravljen za območje celotne regije in za posamezne subregije. Predlog regionalne zasnove se obravnava, potrdi in posreduje $v$ javno razgrnitev. Sosednje regije, $v$ katerih je začeta priprava regionalnih zasnov, se pozove k uskladitvi teh aktov.

\section{Postopek sprejemanja regionalne zasnove}

Predlog regionalne zasnove se javno razgrne v vseh občinah obravnavanega območja in na sedežu Ministrstva za okolje in prostor. Organizirajo se javne obravnave. Na podlagi stališč do pripomb iz javne obravnave in razprave, ki jih potrdi programski svet, pripravi izdelovalec dopolnjen predlog regionalne zasnove, na katerega se pridobijo tudi mnenja pristojnih nosilcev urejanja prostora.

Dopuščena naj bi bila možnost, da se javne obravnave predloga regionalne zasnove ne opravijo obvezno v vsaki posamezni občini udeleženki, temveč skupaj s skupino povezanih občin.

Dopolnjen predlog regionalne zasnove najprej potrdi programski svet. Nato ga potrdi Vlada RS in pošlje občinskim svetom udeleženk v obravnavo in sprejem. Regionalno zasnovo nato sprejmejo občinski sveti občin - udeleženk. Po sprejetju v občinah, regionalno zasnovo sprejme Vlada RS.

Za bistveno poenostavitev postopka je treba preveriti možnost, da program priprave regionalne zasnove ne sprejemajo občinski sveti, temveč programski svet, katerega člani so pooblaščeni predstavniki vseh občin in pristojnih ministrstev.

Sprejeto regionalno zasnovo se objavi v uradnih glasilih občin - udeleženk in v Uradnem listu RS. Veljati začne po ustreznem prehodnem obdobju.

\section{Nosilci urejanja prostora in drugi udeleženci}

$\mathrm{K}$ izdelavi regionalne zasnove je treba vključiti čim širši krog strokovnjakov, ki poznajo prostor in prostorske probleme regije in strokovnjakov, ki imajo ustrezna znanja in izkušnje s področja regionalnega prostorskega planiranja. Zaradi velikega števila vključenih občin in nosilcev urejanja prostora in zaradi kompleksnosti nalog je treba vzpostaviti učinkovit sistem pridobivanja relevantnih podatkov in zagotoviti ustrezno koordinacijo.

Minister za prostor imenuje programski svet na predlog pobudnikov za pripravo regionalne zasnove. Programski svet usmerja in usklajuje pripravo regionalne zasnove. Sestavljajo ga predstavniki ministrstev, iz katerih delokroga so načrtovane prostorske ureditve in predstavniki občin (župani), regionalne razvojne agencije, gospodarstva in nevladnih organizacij iz obravnavanega območja. Svoje odločitve programski svet temelji na sprejetem regionalnem razvojnem programu in drugih veljavnih razvojnih dokumentih, ki veljajo na obravnavanem območju. 
Regionalne razvojne agencije so glede na svojo vlogo primerne za koordinacijo izdelave in organizacijske posle pri izdelavi regionalne zasnove. Imajo namreč tako pooblastilo občin kot tudi države za vodenje projektov na regionalnem nivoju.

Kot nosilci urejanja prostora se s svojimi smernicami in strokovnimi podlagami, ki jih podajo $\mathrm{v}$ prvi fazi priprave regionalne zasnove in $\mathrm{z}$ mnenji $\mathrm{k}$ predlogu regionalne zasnove, postopka priprave regionalne zasnove, udeležijo vsa ministrstva oziroma institucije, katerih delovna področja imajo vpliv na nadaljnji razvoj obravnavanega območja.

\section{Usklajevanje interesov in vključevanje javnosti}

Regionalna zasnova nastaja postopno - z usklajevanjem različnih interesov in razvojnih programov posameznih sektorjev v prostoru, seveda z upoštevanjem sprejetih in potrjenih izhodišč oziroma vizije in ciljev prostorskega razvoja države in občin obravnavanega območja.

$\mathrm{V}$ času priprave regionalne zasnove, zlasti v času javne razgrnitve predloga dokumenta, je o vsebini dokumenta in postopku priprave in sprejemanja, potrebno preko različnih publikacijskih gradiv (zgibanke, brošure) in preko medijev (tiskovne konference, redna poročila ipd.) obveščati javnost.

Ker je regionalna zasnova pravo mesto in $\mathrm{v}$ sistemu prostorskega načrtovanja pravi inštrument, da se z njo za območje več občin usklajeno in skupaj načrtujejo razvojni projekti, ki presegajo razvojne in prostorske potrebe posamezne občine bi kazalo razmisliti o obveznosti izdelave regionalne zasnove prostorskega razvoja kot komplementarnega akta regionalnemu razvojnemu programu oz. še enkrat preigrati možnost nadomestitve Strategije prostorskega razvoja občin. To bi namreč na eni strani pomenilo bolj celovit in prostorsko zaokrožen pristop $\mathrm{k}$ reševanju prostorske problematike, na drugi pa izogib podvajanju postopkom priprave prostorskih aktov za isto območje - $\mathrm{z}$ isto vsebino in podrobnostjo načrtovanja.

$\mathrm{Na}$ koncu pa opozarjam še na po mojem mnenju neprimerno poimenovanje regionalne zasnove prostorskega razvoja, ki bi bilo treba spremeniti, saj že uporaba kar štirih besed za poimenovanje tega akta izraža očitno negotovost glede njegove vsebine oziroma namena. $Z$ njim namreč sploh ne načrtujemo prostorskega razvoja, temveč prostorske ureditve (regionalnega pomena), zato smo predlagali poimenovanje »regionalna zasnova«.

\section{SKLEP}

Ob že znanih pomanjkljivostih in težavah, ki zmanjšujejo pomen in učinkovitost prostorskega planiranja na vseh ravneh, moramo pri uvajanju prostorskega planiranja na regionalni ravni računati še z novimi oziroma dodatnimi problemi. Da bi spodbudili potrebne aktivnosti za njihovo rešitev, ki pa niso neposredno vezane na spreminjanje veljavne zakonodaje, velja opozoriti na nekatera pomembnejša odprta vprašanja in pričakovane probleme, ki so neposredno povezani s pripravo regionalnih zasnov.

\section{Tvorno sodelovanje nosilcev posameznih dejavnosti pri pripravi prostorskih aktov}

Zaostruje se vprašanje zagotovitve tvornega sodelovanja nosilcev posameznih dejavnosti (sektorjev) pri pripravi prostorskih aktov, ki morajo omogočiti uresničitev njihovih razvojnih 
potreb in investicijskih namer. Tega doslej znanega problema ne bo odpravil niti novi Zakon o urejanju prostora, ki nosilcem urejanja prostora $\mathrm{v}$ postopku priprave prostorskih aktov nalaga le izstavitev smernic oziroma pogojev ter mnenj in soglasij. Na tak način izražene in praviloma medsebojno neskladne zahteve ne odražajo vseh stvarnih razvojnih potreb sektorjev in ne omogočajo uskladitev interesov ter planiranja smotrnih prostorskih ureditev. Zato naj bi bile že s programom priprave regionalne zasnove čim bolj konkretno določene naloge posameznih organov in služb, ki jih morajo kot nosilci urejanja prostora opraviti pri pripravi tega akta. Njihove naloge morajo poleg zagotovitve lastnih strokovnih podlag obsegati tudi sodelovanje pri oblikovanju predlogov odločitev.

\section{Medsebojna usklajenost regionalnih zasnov sosednjih regij}

Nujno bo potrebno zagotoviti medsebojno usklajenost regionalnih zasnov, zlasti sosednjih regij. Zakon o urejanju prostora namreč zahteva le skladnost prostorskih aktov na istem območju, še naprej pa ostaja odprto vprašanje način priprave in sprejemanja usklajenih prostorskih ureditev, ki so povezana z ureditvami na sosednjih območjih. V programu priprave prostorskega akta bi bilo torej potrebno določiti področja usklajevanja s sosednjimi območji, naloge in njihove nosilce. Za uskladitev prostorskih ureditev državnega in regionalnega pomena bi morala $\mathrm{v}$ največji meri skrbeti ministrstva na podoben način, kot sedaj poteka njihovo sodelovanje pri ugotavljanju usklajenosti občinskih prostorskih planov z državnim, vendar v tem primeru ne le s postavljanjem pogojev in zahtev, temveč predvsem z zagotovitvijo in usklajevanjem strokovnih podlag za doseganja stvarne skladnosti odločitev.

\section{Univerzalnost regionalnih zasnov}

Zakon o urejanju prostora dopušča možnost, da lahko regionalna zasnova nadomesti pro-storski plan občine v njegovih posameznih delih. Opozoriti je potrebno na nevarnost deformacije osnovnega namena regionalne zasnove, ki bo preobložena z nujno potrebnimi podrobnimi odločitvami glede urejanja prostora na občinski ravni, namesto, da bi reševala ključne prostorske probleme regionalnega značaja oz. tiste, za katere je smiselno, da jih država in lokalne skupnosti rešujejo skupno.

\section{Kakovost in učinkovitost strokovnega dela na področju prostorskega planiranja}

Končno velja opozoriti še na znani problem kakovosti in učinkovitosti strokovnega dela na področju prostorskega planiranja, ki bo z novimi oziroma dodatnimi nalogami na regionalni ravni še bolj zaostren. Problem izvira predvsem iz pomanjkanja ustrezno usposobljenih kadrov tako v upravnih organih in službah na državni in občinski ravni, kot tudi v organizacijah, ki izdelujejo prostorske akte. Ugotavljamo tudi pomanjkljivo informiranost drugih udeležencev $\mathrm{v}$ procesu priprave in uresničevanja prostorskih aktov. Skrbeti je potrebno za strokovno usposabljanje kadrov za potrebe regionalnega prostorskega planiranja na treh ravneh:

- osnovno naj bi potekalo v okviru univerzitetnega izobraževanja, v dodiplomskem in še posebej podiplomskem študiju,dodatno usposabljanje bo namenjeno strokovnjakom, ki že ali bodo opravljali naloge na področju prostorskega planiranja na regionalni ravni, 
- na tretji ravni usposabljanja pa naj bi bilo zagotovljeno stalno informiranje in izobraževanje vseh udeležencev v procesu regionalnega prostorskega planiranja.

\section{Pogled v čas uveljavitve celovitega razvojnega planiranja}

$\mathrm{Na}$ podlagi veljavne zakonodaje in predlogov za spremembo le te v smislu večje vloge in pomena regionalnih zasnov, si bomo $\mathrm{v}$ naslednjem proračunskem obdobju strokovno in finančno prizadevali za izdelavo regionalnih zasnov, s ciljem do leta 2013 izdelati jih tudi za vse ostale regije in problemska območja v Sloveniji.

Doseženi bodo ključni cilji, ki smo si jih zastavili, predvsem celovit, trajno uravnotežen, prostorski razvoj obravnavanih območij in ponovna uveljavitev prostorskega planiranja na regionalni ravni.

\section{Literatura}

Oddelek za regionalne zasnove prostorskega razvoja - redno delo, iz katerega je nastala večina besedila, uporabljenega v prispevku. MOP - Urad za prostorski razvoj. Ljubljana, 20012005.

Pogačnik, A., 2001: Urejanje prostora in varstvo okolja. Mladinska knjiga. Ljubljana, 1992.

Politika prostorskega razvoja Republike Slovenije, MOP - Urad RS za prostorsko planiranje. Ljubljana.

Pravilnik o podrobnejši vsebini, obliki in načinu priprave regionalne zasnove prostorskega razvoja ter vrstah njenih strokovnih podlag. Uradni list RS, št. 24/04.

Strategija prostorskega razvoja Slovenije. 2004: MOP - Urad RS za prostorski razvoj. Ljubljana.

Strategija regionalnega razvoja Slovenije. 2001: MG. Ljubljana.

Vodilna načela za trajnostni prostorski razvoj evropske celine. 2000: CEMAT. Hannover, 2000.

Vrišer, I., 1978: Regionalno planiranje. Mladinska knjiga. Ljubljana.

Zakon o spodbujanju skladnega regionalnega razvoja. Uradni list RS, št. 60/99, 52/02-ZDU-1 in 56/03.

Zakon o urejanju prostora. Uradni list RS, št. 110/02, 8/03 - popr. in 58/03-ZZK-1.

Zakona o varstvu okolja. Uradni list RS, št. 41/04.

Zakona o ohranjanju narave. Uradni list RS, št. 96/04, uradno prečiščeno besedilo. 


\section{ADVANTAGES AND RISKS OF SPATIAL PLANNING AT REGIONAL LEVEL}

\section{Summary}

The article states and arguments the reasons for renewed enforcement of spatial planning on regional level through Regional Concepts of Spatial Development (Regional Concepts). These planning acts were, by the new Spatial Planning act, legalized in Slovenian spatial planning system in 2002.

The focus of the article deals with spatial planning on regional level. The motives for and the procedure of elaboration and enforcement of Regional Conceptions have been presented together with content concept of the act. The content of each Regional Conception depends on its territory and on the economic and social needs of people who live there.

The procedure of elaboration and enforcement of Regional Concepts is presented in detail. The explanation of every step in the procedure is interpreted also from the point of view of the problems which we face through every day practical experience. These problems have already been presented to the Ministry for the Environment and Spatial Planning where amandments to the Spatial Planning Act are being prepared. with intention that planning at regional level will, through the enforcement of Regional Concepts, gain its proper role and contribute to integral sustainable development.

The conclusion brings some of the most important pending questions and expected problems which are directly linked to Regional Conceptions of Spatial Development. 